\title{
Making Formulation of Tea Bags Combination of Kecibeling Leaves (Strobilanthes crispa (L.) Blume), Salam Leaves (Syzygium polyanthum (Wight.) Walp.) and Meniran Herbs (Phyllanthus niruri L.) As Antioxidants
}

\author{
Desy Natalia Siahaan ${ }^{1}$, Salmah Handayani Lubis ${ }^{1}$, Muflihah Fujiko ${ }^{1}$, Ernawaty Ginting ${ }^{1}$, Pian \\ Alatas Purba ${ }^{1}$ \\ ${ }^{1}$ Faculty of Pharmacy, Universitas Tjut Nyak Dhien Medan, Indonesia \\ e-mail: salmahhandayani32@gmail.com
}

\begin{abstract}
The more incessantly the motto "back to nature" various types of plants in Indonesia are used by the community as traditional medicine. Kecibeling plants, salam and meniran herbs are one of the traditional medicinal ingredients that are often used. The potential development of the combination of kecibeling leaves, bay leaves and meniran herbs was chosen as a tea bag preparation because it is simple, cheap, and practical. The purpose of this study was to formulate a combination of kecibeling leaves, salam and meniran herbs as an antioxidant. This research was conducted by collecting fresh leaves of the kecibeling plant, salam and meniran herbs from Pematangsiantar, then used as simplicia and then formulated in teabags with varying weights. Then the formula is tested for characteristics which include water content test, $\mathrm{pH}$ test of the preparation, organoleptic test including hedonic test and antioxidant activity test.The results of testing the water content in each formula are $3.72 \% ; 5.07 \%$ and $6.81 \%$. The results of the $\mathrm{pH}$ test of teabag preparations from each formula were 6.7-7.Based on the results of the Hedonic test, Formula II with a weight of $0.95 \mathrm{~g}$ was preferred by the panelists, so it was continued to be tested for activity as an antioxidant. The results of the antioxidant activity test showed that in Formula II $(0.95 \mathrm{~g})$ has antioxidant activity with the category "Medium".
\end{abstract}

Keywords: antioxidant activity; characteristics; combination; simplicia; tea bag

\section{INTRODUCTION}

Free radicals are atoms or molecules that contain an unpaired electron in their outermost orbital. Free radicals are unstable and highly reactive, i.e. they tend to react with other molecules to achieve stability. Radicals with high reactivity can start a chain reaction in one formation, giving rise to abnormal compounds and starting a chain reaction that can damage important cells in the body (Badarinath $e t$ al., 2010).

Antioxidants are electron donating compounds. Antioxidants work by 
donating one electron to compounds that are oxidants so that the activity of these oxidant compounds can be inhibited. Antioxidants stabilize free radicals by complementing the electron deficiency of free radicals, and inhibit the chain reaction of free radical formation (Liberty, 2012).

The search for sources of antioxidants is more directed at natural antioxidants, especially those from plants. Natural antioxidants have a better level of safety. Flavonoids are one of the antioxidants that are widely distributed in plants (Winarsi, 2007).

Kecibeling (Strobilanthes crispus (L.) Blume) is a type of plant that is generally planted by the community as a hedge (Dalimartha, 2007). Kecibeling leaves (Strobilanthes crispus (L.) Blume) contain large amounts of active compounds such as minerals (potassium, calcium, sodium, potassium, iron and phosphorus), watersoluble vitamins (C, B1, and B2), vitamin E, catechins, tannins.

, coumarins, flavonoids, and steroids (Setyaningsih, 2008).

Salam leaves have been studied to contain flavonoids which have antioxidant activity (Agus and Agustin, 2008). Flavonoids can improve endothelial function. This effect is an advantage of flavonoids on the risk of cardiovascular disease (Agus and Agustin, 2008).

Salam leaves is a plant that is often found in Indonesia. Plants that have a Latin name (Syzygium polyanthum (Wight.) Walp.) as a medicinal plant native to Indonesia are widely used by the public to reduce cholesterol, diabetes, hypertension, gastritis, and diarrhea.

Salam leaves are known to contain flavonoids, selenium, vitamin $\mathrm{A}$, and vitamin $\mathrm{E}$ which function as antioxidants (Riansari, 2008). Bark, roots and leaves can be used as a remedy for itching. And the wood is used for building materials (Sembiring, Winarti and Baringbing, 2008).
Meniran (Phyllanthus niruri L.) is a wild plant of the Euphorbiaceae tribe that lives in tropical climates. In Indonesia this plant is very easy to find on the edge of the road, vacant land, gardens, rivers and even in the yard of the house. The results of research on the chemical content of meniran herbs showed that there were chemical compounds of essential oils, flavonoids, alkaloids, arbutin, glycosides, anthraquinones, phenolic compounds, and tannins (Sudarsono et al., 1996).

The potential development of the combination of kecibeling leaves, salam leaves and meniran herbs was chosen to be a tea bag preparation, because of the advantages of the method of making teabag preparations which are simple, inexpensive, and practical. Currently, the preferred form of tea preparation is tea bags, because of its practical preparation. This is also interesting and unique, because this tea is not made from tea leaves but from kecibeling leaves, salam leaves and meniran herbs.

\section{MATERIAL AND METHODS}

Kecibeling leaves (Strobilantes crispa (L.) Blume), salam leaves (Syzygium polyanthum (Wight.) Walp.), meniran herbs (Phyllanthus niruri L.), pH 4 solution, $\mathrm{pH} 7$ solution, methanol, distilled water, silica gel and 2 2-diphenyl-1picrylhydrazyl (DPPH), Blender (Miyako), Desiccator, Impluse Sealer Q2, Drying cabinet, $\mathrm{pH}$ meter (Lutron $\mathrm{PH}$ 201), Shimadzu UV-Vis 1800 Spectrophotometer, Digital scale (AND HT-120*).

\section{Procedures}

\section{Simple material processing}

The plants used were kecibeling leaves, Salam leaves and meniran herbs taken in the Pemangsiantar area (Figure 1). A total of $1 \mathrm{~kg}$ of each plant was processed into simplicia with several stages, namely sampling, wet sorting, 
washing, chopping, drying, dry sorting and refining (Directorate General of POM, 1989) at a temperature of $45-60{ }^{\circ} \mathrm{C}$ for \pm 3 days in a drying cabinet. The results of plant simplicia can be seen in (Figure 2).

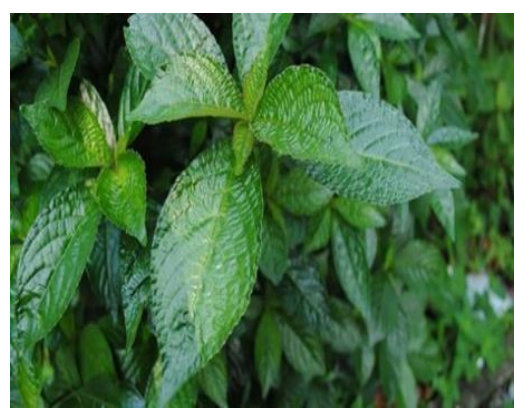

Kecibeling leaves

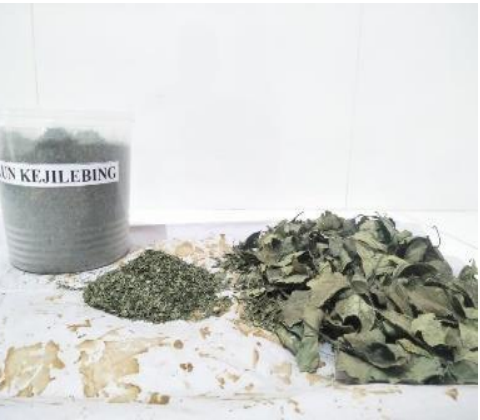

Kecibeling leaves simplicia

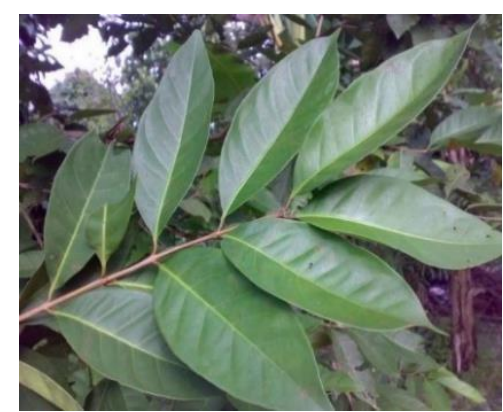

Salam leaves

Figure 1. Plant pictures

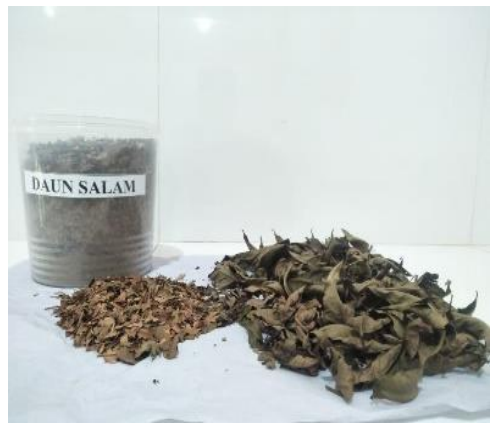

Salam leaves simplicia

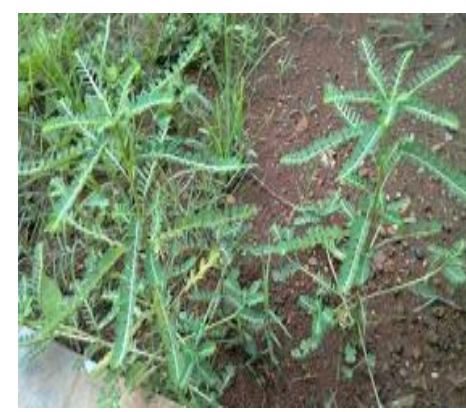

Meniran herb

Figure 2. Simple picture

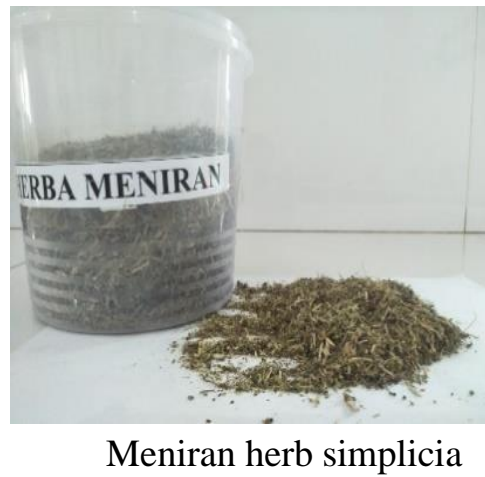

meter. The $\mathrm{pH}$ meter was calibrated using

\section{Water content test}

Testing the water content by means of the dish in an oven for 15 minutes at a temperature of $105^{\circ} \mathrm{C}$, then the cup is cooled in a desiccator for 15 minutes and weighed. The formula was weighed and put in a dry cup, then baked at a temperature of $105^{\circ} \mathrm{C}$ for 5 hours, cooled in a desiccator for 15 minutes and weighed (B1). After that the cup + sample was dried again in the oven for \pm 30 minutes at a temperature of $105^{\circ} \mathrm{C}$ to constant weight, then cooled again in a desiccator for 15 minutes and weighed (B2) (AOAC, 2012).

$$
\% \text { water content }=\frac{W 1-W 2}{W 1} \times 100 \%
$$

\section{Preparation of pH test}

Measurement of $\mathrm{pH}$ was carried out on formulations I, II, and III using a $\mathrm{pH}$ 
a phosphate buffer solution at $\mathrm{pH} 4$ and 7 . Washed the electrodes with water and then dried and then dipped the electrodes into each formula in turn, then waited a few minutes until the results showed a constant pH (SNI 6986-11, 2019).

\section{Organoleptic testing}

Parameters for testing the organoleptic characteristics of tea bags include: color, aroma, and taste. The organoleptic test uses a numerical scale to assess the level of panelists' acceptance of the product. The method used is the preference test (Hedonic test) using 20 panelists. The panelists were asked to taste and rate the tea bag products according to the scoring sheet. 


\section{Antioxidant Activity Test DPPH method principle}

The ability of the test sample to immerse the DPPH free radical oxidation process in methanol solution (so that the DPPH color changes from purple to yellow) with an $\mathrm{IC}_{50}$ value (concentration of the test sample capable of reducing free radicals by $50 \%$ ) as a parameter to determine the antioxidant activity of the sample (Molyneux, 2016).

\section{Preparation of DPPH mother liquor}

The DPPH solution was prepared by weighing $50 \mathrm{mg}$ of DPPH then put in a 100 $\mathrm{ml}$ volumetric flask and made up to the mark with methanol.

\section{Measurement of the maximum absorption wavelength of DPPH}

A total of $2 \mathrm{ml}$ of the DPPH solution was put into a volumetric flask and then filled with methanol until the marking line. Determine the maximum wavelength, measure the absorbance at a wavelength of $400-800 \mathrm{~nm}$. The maximum absorbance was obtained as the DPPH wavelength and repeated 3 times.

\section{DPPH operating time measurement}

A total of $2 \mathrm{ml}$ of the DPPH solution was put into a volumetric flask and then filled with methanol until the marking line. The absorbance was measured at the maximum wavelength and repeated 3 times.

\section{RESULTS AND DISCUSSION Tea Bag Preparation Formulation}

Simplicia powder kecibeling leaves (Strobilantes crispa (L.) Blume), salam leaves (Syzygium polyanthum (Wight.) Walp.) and meniran herb (Phyllanthus niruri L.) formulated into 3 formulations (Table 1). Tea bag formulations were made with various concentrations, each of which was put in a tea bag (Figure 3).

Table 1. Simple combination formulation

\begin{tabular}{|c|c|c|c|c|c|}
\hline \multirow{2}{*}{ No } & \multirow{2}{*}{ Formula } & \multicolumn{3}{|c|}{ Simplicia Combination Comparison } & \multirow{2}{*}{$\begin{array}{c}\text { Tea Bag Weight } \\
\text { (grams) }\end{array}$} \\
\hline & & Kecibeling leaves & Salam leaves & Meniran herb & \\
\hline 1 & I & 0.4 & 0.2 & 0.05 & 0.65 \\
\hline 2 & II & 0.5 & 0.3 & 0.15 & 0.95 \\
\hline 3 & III & 0.6 & 0.4 & 0.25 & 1.25 \\
\hline
\end{tabular}

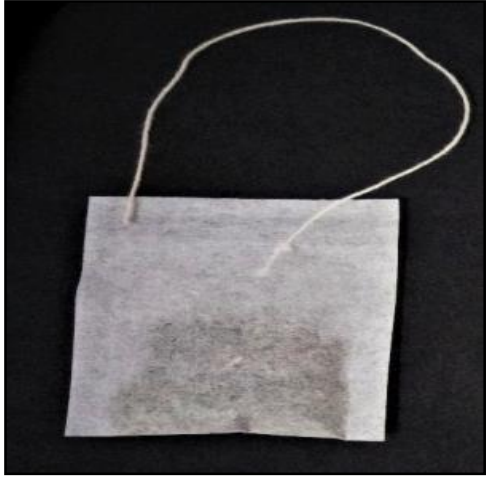

Formula I (0.65 g)

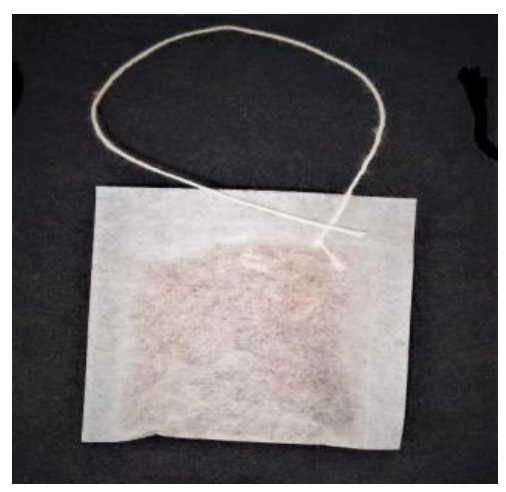

Formula II $(0.95 \mathrm{~g})$

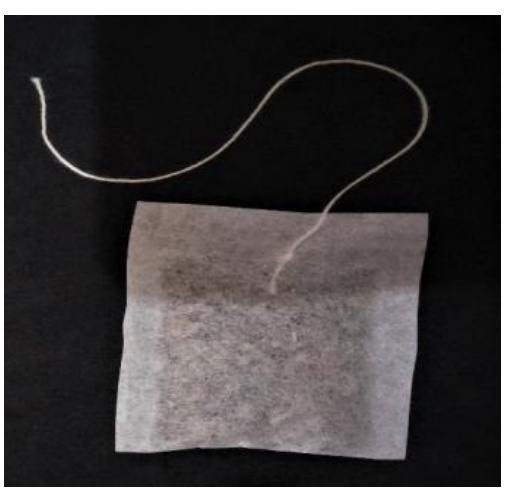

Formula III $(1.25 \mathrm{~g})$

Figure 3. Preparation of tea bags

The formulations in (Table 1) were put in tea bags (Figure 3). Then the water content test, $\mathrm{pH}$ test preparation, organoleptic test (Hedonic test), and testing of antioxidant activity using the DPPH method. 


\section{Water content test results}

Water content testing carried outin various concentrations is to meet the requirements (Depkes RI, 2000) namely: no more than $10 \%$. Observation of water content aims to provide a minimum limit or range of the amount of water content in simplicia (Depkes RI, 2000). The results of this water content test give the average value for each formula, respectively, which is $3.72 \%$; $5.07 \%$ and $6.81 \%$ (Graph $1)$.

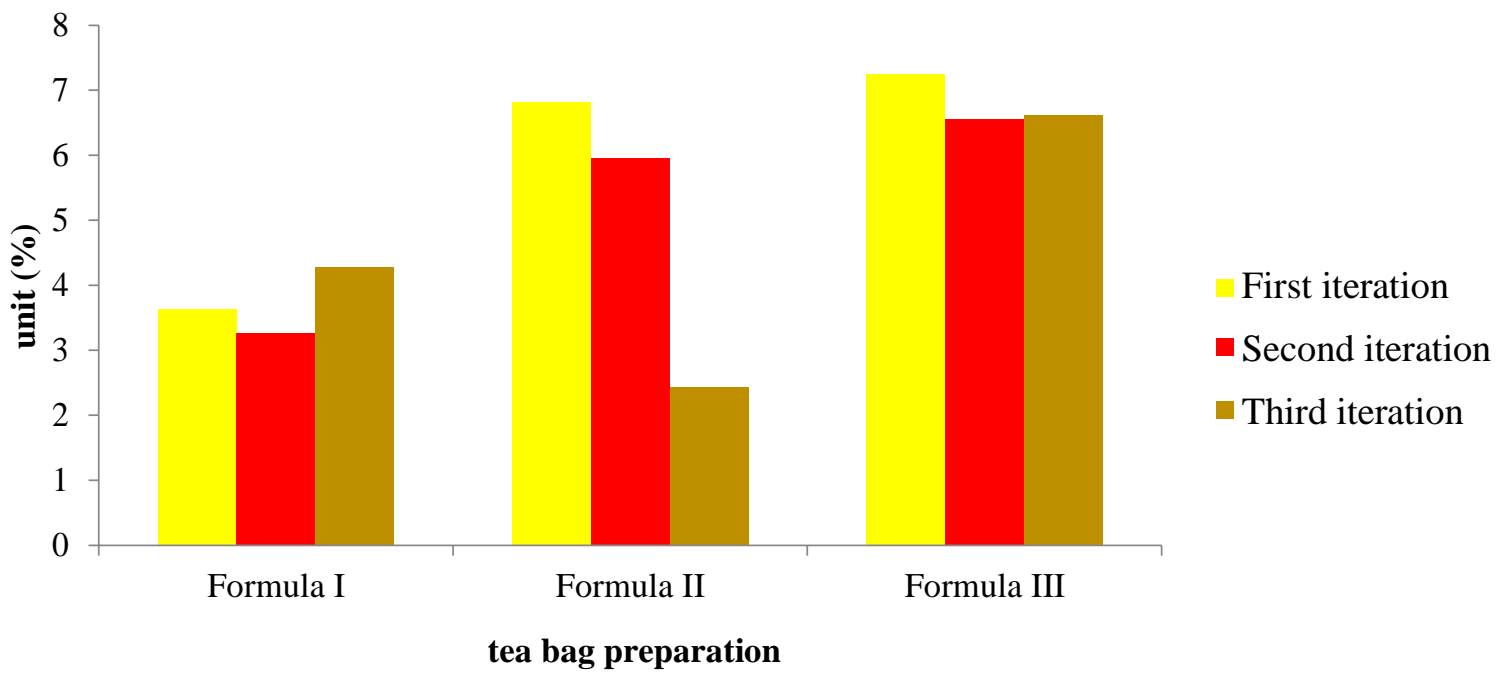

Graph 1. Water content test results

\section{pH test results}

The $\mathrm{pH}$ of the preparation was determined using a $\mathrm{pH}$ meter. Measurement of the $\mathrm{pH}$ of the preparation was carried out on all teabag formulations. From the experiments conducted, the data obtained are in (Table 2).

Table 2. Data on the results of testing the $\mathrm{pH}$ of tea bag preparations

\begin{tabular}{cccccc}
\hline \multirow{2}{*}{ No } & \multirow{2}{*}{ Formula } & \multicolumn{3}{c}{$\mathrm{pH}$} & \multirow{2}{*}{ Average } \\
\cline { 3 - 5 } & & 1 & 2 & 3 & \\
\hline 1 & I & 6.5 & 6.8 & 7.0 & 6.7 \\
\hline 2 & II & 7.0 & 7.0 & 7.0 & 7.0 \\
\hline 3 & III & 7.0 & 7.0 & 7.1 & 7.03 \\
\hline
\end{tabular}

Information : 1: First iteration, 2: Second iteration, 3: Third iteration.

On (Table 2) shows that the consumption. preparation of tea bags from kecibeling leaves simplicia, salam leaves and meniran herb obtained $\mathrm{pH}$ results in the range of 6.7-7.0. This shows that the tea bag preparations meet the requirements of 4.0-7.0 (SNI 6986-11, 2019). The $\mathrm{pH}$ measurement aims to determine whether the $\mathrm{pH}$ of the formulated tea bag preparation is not too acidic or alkaline for 


\section{Organoleptic test results}

On organoleptic testing the method used is the preference test (Hedonic test) using as many as 20 panelists or volunteers. From the 20 panelists who chose the preferred tea bag preparations based on color, aroma and taste, namely formula II tea bag preparations (Table 3). 
Table 3. Preferred value data for tea bags

\begin{tabular}{cccccc}
\hline \multirow{2}{*}{ No. } & \multirow{2}{*}{ Formula } & \multicolumn{3}{c}{ Organoleptic Test } & \multirow{2}{*}{ Information } \\
\cline { 3 - 5 } & & Color & Scent & Flavor & \\
\hline 1 & I & 3 & 3 & 3 & Neutral \\
\hline 2 & II & 3 & 4 & 4 & Like \\
\hline 3 & III & 3 & 4 & 2 & Neutral \\
\hline
\end{tabular}

Description of Preferred Value: 1: Dislike very much, 2: Dislike, 3: Neutral, 4: Like, 5: Really like

The test results of the antioxidant activity of tea preparations dip

Testing the antioxidant activity of teabag preparations was carried out by UV-Vis spectrophotometry using the DPPH method (2,2-diphenyl-1picrylhydrazyl). This method is the most simple, easy, fast method and only requires a small sample to evaluate the antioxidant activity of natural compounds.

The results of the measurement of the maximum absorption wavelength of DPPH

Testing of antioxidant activity begins with measuring the maximum wavelength of the DPPH solution in methanol using UV-Vis spectrophotometry in the wavelength range of $400-800 \mathrm{~nm}$. The results of measurements carried out for 3 repetitions showed the maximum absorption of DPPH at a wavelength of $514 \mathrm{~nm}$ with an absorbance value of 0.530 .

\section{Operating time measurement results}

The results of the operating time measurement were carried out on the DPPH solution and formula II + DPPH each was repeated 3 times. At 8-12 minutes the DPPH solution showed a stable absorbance, and at 17-22 minutes the formula II + DPPH showed a stable absorbance, where the sample reacted perfectly with the DPPH solution.

The results of the analysis of the percentage of antioxidant activity

The antioxidant activity of formula II tea bag preparations can be seen in fig (Table 4).

Table 4. Antioxidant activity of formula II tea bag preparations

\begin{tabular}{cccccccc}
\hline \multirow{2}{*}{ No $\begin{array}{c}\text { Sample Concentration } \\
(\mu \mathrm{g} / \mathrm{mL})\end{array}$} & \multicolumn{3}{c}{ Absorbance } & \multicolumn{3}{c}{$\begin{array}{c}\text { Antioxidant Activity } \\
(\%)\end{array}$} \\
\cline { 2 - 8 } & 0 & 1 & 2 & 3 & 1 & 2 & 3 \\
\hline 1 & 95 & 0.280 & 0.285 & 0.247 & $47.66 \%$ & $46.73 \%$ & $53.83 \%$ \\
\hline 2 & 190 & 0.133 & 0.117 & 0.122 & $75.14 \%$ & $78.13 \%$ & $77.19 \%$ \\
\hline 3 & 380 & 0.083 & 0.095 & 0.095 & $84.48 \%$ & $82.24 \%$ & $82.24 \%$ \\
\hline 4 & 570 & 0.101 & 0.090 & 0.093 & $81.12 \%$ & $83.17 \%$ & $82.61 \%$ \\
\hline 5 & 760 & 0.110 & 0.089 & 0.083 & $79.43 \%$ & $83.36 \%$ & $84.48 \%$ \\
\hline 6 & 950 & 0.112 & 0.088 & 0.081 & $79.06 \%$ & $83.55 \%$ & $84.85 \%$ \\
\hline 7 & & &
\end{tabular}

Information: 1: First iteration, 2: Second iteration, 3: Third iteration.

On (Table 4) showed a decrease in absorbance at concentrations of 95 and $190 \mathrm{~g} / \mathrm{mL}$ and a very significant decrease at a concentration of $380 \mathrm{~g} / \mathrm{mL}$, then at concentrations of 570,760 and $950 \mathrm{~g} / \mathrm{mL}$ an increase. This shows a non-positive relationship between concentration and absorbance levels. In (Table 4) it can also be seen that there was an increase in 
antioxidant activity with a decrease in absorbance.

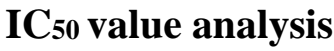

The $\mathrm{IC}_{50}$ values for simplicia tea bags of kecibeling leaves (Strobilantes crispa (L.) Blume), salam leaves (Syzygium polyanthum (Wight.) Walp.) and meniran herb (Phyllanthus niruri L.) in formula II can be seen in (Table 5). The regression equation was obtained from the sample concentration data and \% antioxidant activity.

Table 5. $\mathrm{IC}_{50}$ value of formula II tea bag preparations

\begin{tabular}{cccc}
\hline No & Repetition & Regression Equation & $\begin{array}{c}\text { IC50 } \\
(\mu \mathrm{g} / \mathrm{mL})\end{array}$ \\
\hline 1 & I & $\mathrm{Y}=0.05900 \mathrm{x}+39.0030$ & 186.39 \\
\hline 2 & II & $\mathrm{Y}=0.06396 \mathrm{x}+38.4025$ & 181.32 \\
\hline 3 & III & $\mathrm{Y}=0.06249 \mathrm{x}+40.1653$ & 157.37 \\
\hline
\end{tabular}

In (Table 5) shows that the $\mathrm{IC}_{50}$ value of tea bag preparations in repetition I was $186.39 \mathrm{~g} / \mathrm{mL}$, repetition II was 181.32 $\mathrm{g} / \mathrm{mL}$ and repetition III was $157.37 \mathrm{~g} / \mathrm{mL}$. From the results of the $\mathrm{IC}_{50}$ value obtained, the tea bag preparation is included in the "Medium" category as an antioxidant. The lower the $\mathrm{IC}_{50}$, the higher the antioxidant activity (Figure 4).

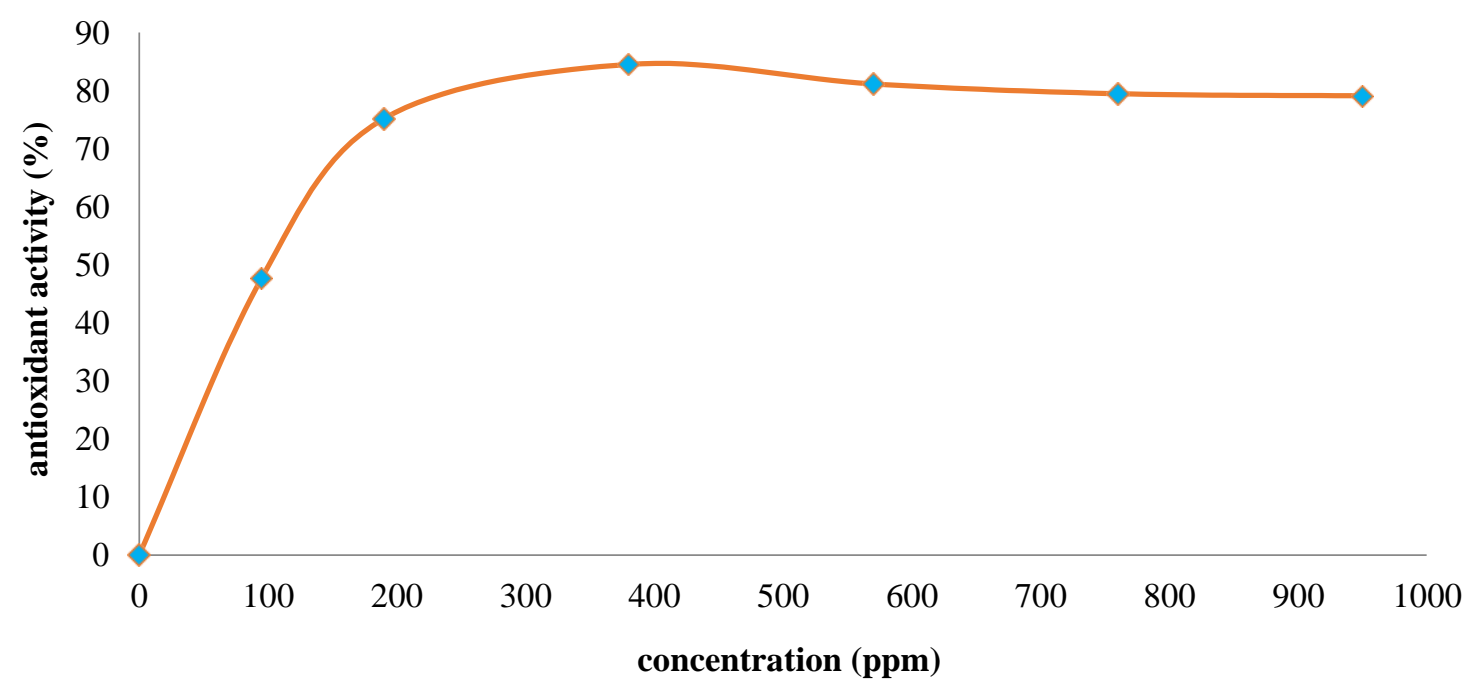

Figure 4. Concentration curve of formula II tea bag preparation with antioxidant activity 
Table 6. Relationship of IC50 Value to Antioxidant Activity

\begin{tabular}{ccc}
\hline No. & IC $_{\mathbf{5 0}}$ & Aktivitas Antioksidan \\
\hline 1. & $<50 \mu \mathrm{g} / \mathrm{ml}$ & Sangan Kuat \\
\hline 2. & $50 \mu \mathrm{g} / \mathrm{ml}$ & Kuat \\
\hline 3. & $\mathbf{1 0 1} \boldsymbol{\mu g} / \mathbf{M l}-\mathbf{2 5 0} \boldsymbol{\mu g} / \mathbf{m l}$ & Sedang \\
\hline 4. & $250 \mu \mathrm{g} / \mathrm{Ml}-500 \mu \mathrm{g} / \mathrm{ml}$ & Lemah \\
\hline 5. & $>500 \mu \mathrm{g} / \mathrm{ml}$ & Tidak Aktif \\
\hline
\end{tabular}

\section{CONCLUSION}

The results obtained from testing the antioxidant activity of the formula for the combination of kecibeling leaf simplicia, bay leaf and meniran herb using a UV-Vis spectrophotometer at a wavelength of $515 \mathrm{~nm}$ have antioxidant activity with an IC50 value of $186.39 \mathrm{~g} / \mathrm{mL}$ with the category "Medium" . 


\section{REFERENCES}

Adibi, S. Nordan, H. Ningsih, S, N. et al., (2017). Antioxidant and Antibacterial Activity of Leaves Extract of Strobilanthes Crispus Bl (Keji Beling) Against Staphylococcus Aureus and Escherichia Coli. ALOTROP Journal of Education and Chemistry. Vol 1(2): 148-154.

Agus, S. Agustin, W, S. (2008). The Use of Salam Leaves (Eugenia polyantha Wight) in Dentistry. Dental Journal. 41(3); 147-150.

Area. Irfan. (2013). Benefits and Efficacy Violent Glass. (On line). (- See more at:http://irfanarea.blogspot.com/2013/06/benefi ts-dan efficacykejibelmg.html\#sthash.26 0kMTGi.dpuf, accessed December 01,2013

Association of Official Analytical Chemistry. (2012). Official Method of Analysis. AOAC. Gaitherburg. USA

POM RI. (2006). Meniran (Phyllanthus niruri L.). (The Latest Scientific Data Series on Medicinal Plants). Directorate of Native Indonesian Medicines. Pages 13.

POM Agency. (2006). Meniran (Medicinal Plant Series). Directorate of Native Indonesian Medicines. $15 \mathrm{p}$.

Badarinath, A, V. Rao, K, M, Chetty, C, M, S. Ramkanth, S. Rajan, T, V, S. Gnana prakash, K. (2010). A Review on In-Vitro Antioxidant Methods: Comparisons, Correlations and Considerations. International Journal of Pharm Tech Research. Vol (2): 12761285.

Dalimartha, S. (2007). Atlas of Indonesian Medicinal Plants. Agromedia Library. Jakarta.

Indonesian Ministry of Health. (2000). General Standard Parameters of Medicinal Plant Extracts.
Jakarta: Ministry of Health of the Republic of Indonesia. Thing. 330.

Directorate General of POM. (2000). General Standard Parameters of Medicinal Plant Extracts. Jakarta: Indonesian Ministry of Health. Pages 3-5, 10-11

Directorate General of POM. (1989). Indonesian Medical Materials. Edition VI. Jakarta: Indonesian Ministry of Health. Page 41.

Fitriana, A. Harun, N. Yusmarini. (2017). Quality of Herbal Tea Leaves Vile Beling With Long Drying Treatment. SAGU: Agricultural Science and Technology Journal. Vol. 16(2): 34-41.

Handayani, V. Nurfadillah. (2012). Pharmacognostic Study of Green Meniran Herbs (Phyllanthus Niruri L.) and Red Meniran Herbs (Phyllanthus Urinaria L.). Journal of Indonesian Fitofarmaka, Vol 1(1)

Liasambu, S, H. Rusli, N. (2018). Formulation of Herbal Tea Bags Made from Salam Leaves (Eugenia polyantha Wight) Combination of Soursop Leaves (Annona muricata L.) as an Anti-

Hypertension Alternative. Journal of Pharmaceutical and Medicinal Sciences. Vol.3(1): 6-9.

Liberty, P., Malangia., Meiske, S, S. Jessy, J, E, P. (2012).

Determination of Tannin Content and Antioxidant Activity Test of Avocado (Persea americana Mill) Seed Extract. Journal of Mathematics and Natural Sciences Unsrat Online. Vol.1(1): 5.

Nasution, M, R. Syamira. (2019). Antioxidant Activity of Herbal Tea From a Mixture of Bitter Melon Flesh (Momordica charantia L.), Red Ginger (Zingiber officinalle Roscoe) and Temulawak(Curcuma xanthorrhiza Roxb). Photon Journal.Vol.10(2): 167. 
Riansari, A. (2008). Effect of Administration of Salam Leaves Extract (Eugenia polyantha) on Serum Total Cholesterol Levels of Hyperlipidemic Male Wistar Rats. Re-downloaded from http://eprints.undip. ac.id/24176/1/Anugerah_R.pdf.

Sembiring, S., Winarti, C., \& Baringbing, B. (2008). Identification of Chemical Components of Salam Leaves Oil (Eugenia polyantha) from Sukabumi and Bogor. Redownloaded from http://balittro.litbang.deptan. go.id/indo/images/publikasi/bul.v ol.14. no.2/BagemDaunSalam.pdf.

Setyaningsih, D. (2008). The Effect of Kecibeling Leaves Infusion Test on Reducing Blood Glucose Levels in Male Rabbits. Essay. Muhammadiyah University, Surakarta. Pages 56-60.
SNI, 6986-11. (2019). Water and WastePart II: How to Test the Degree of Acidity $(\mathrm{pH})$ Using a $\mathrm{pH}$ Meter. National Standardization Body. Jakarta.

Sudarsono. Afus, A, P. Gunawan, D. (1996). Phyllanthus miruri L.) (Euphorbiaceae). Meniran in Medicinal Plants. Research Results, Properties and Uses, Jakarta; Agromedia Pustaka. Pages 145157.

Tonahi, J, M, M. Nuryanti, S. Suherman. (2014). Antioxidants From Red Betel Leaves (Piper crocatum). Chemical Academic Journal. Vol.3(3): 383-389.

Winarsi, H. (2007). Natural Antioxidants and Free Radicals. Yogyakarta: Kanisius. Pages 30-34. 